\title{
Esplenite traumática em bovinos - relato de 16 casos
}

Tatiane Vitor da Silva", José Augusto Bastos Afonso, Carla Lopes de Mendonça, Nivaldo de Azevedo Costa, Nivan Antônio Alves da Silva, Rodolfo José Cavalcanti Souto, Luiz Teles Coutinho, José Cláudio de Almeida Souza, Jobson Filipe de Paula Cajueiro

Universidade Federal Rural de Pernambuco (UFRPE), Garanhuns, PE, Brasil

*Autor correspondente

e-mail: ta_ty_vitor@hotmail.com

\section{Resumo}

A esplenite traumática é uma enfermidade pouco comum na clínica de ruminantes. Somente 2 a $14 \%$ dos animais diagnosticados com reticuloperitonite traumática (RPT) apresentam esplenite traumática como sequela. Isso pode ser atribuído à configuração anatômica e localização do baço, que o torna menos propenso a traumas por corpos estranhos perfurantes. Este trabalho tem por objetivo relatar os achados clínicos, laboratoriais e anatomopatológicos da esplenite traumática em 16 bovinos adultos atendidos na Clínica de Bovinos, Campus Garanhuns - Universidade Federal Rural de Pernambuco (CBG/UFRPE), entre os anos de 2009 e 2016. Os casos de esplenite traumática no período estudado corresponderam a 15\% de todas as reticulites traumáticas. Os dados foram obtidos a partir dos prontuários clínicos e laudos de necropsia. Redução do apetite e da produção de leite foram as principais queixas relatadas pelos proprietários. No exame clínico, as principais alterações observadas foram apatia, desidratação, taquicardia e hipomotilidade ruminal e intestinal. Nos achados hematológicos constatou-se redução do número de hemácias, hematócrito e hemoglobina, além de hiperproteinemia $(9,41 \mathrm{~g} / \mathrm{dL})$, hiperfibrinogenemia $(1028,57 \mathrm{mg} / \mathrm{dL})$ e leucocitose por neutrofilia $(45123,21 \mu \mathrm{L})$. Na ultrassonografia, a maioria dos animais manteve o padrão bifásico de contração reticular presente, no entanto, alguns apresentaram baixa amplitude de deslocamento ou ausência do mesmo. Nas imagens do baço, os achados mais frequentes foram: irregularidades da cápsula, conteúdo anaecóico ou hipoecóico entre baço e retículo, ecogenicidade reduzida do parênquima e áreas circulares com conteúdo hipoecoico delimitadas por cápsula hiperecoica, sugestivo de abscessos. Foram eutanasiados 10 animais, um veio a óbito e cinco retornaram para a propriedade por decisão dos proprietários. Os principais achados de necropsia foram peritonite crônica, localizada na região crânio-ventral do abdômen, retículo aderido aos órgãos adjacentes, esplenomegalia e esplenite abscedativa. Na maioria dos casos foi possível localizar e identificar o corpo estranho metálico (CEM), arames medindo entre 3 a $11 \mathrm{~cm}$. A anemia observada é atribuída 
ao caráter crônico da enfermidade. A elevação do fibrinogênio e da proteína plasmática ocorrem em resposta à inflamação e a leucocitose expressiva caracteriza a severidade da enfermidade pela extensa necrose supurativa. A ultrassonografia de vacas com RPT revela que as contrações bifásicas do retículo se encontram diminuídas ou indistintas, e revela uma hipomotilidade. Os abscessos reticulares são uma complicação comum, podendo ser localizados entre o retículo e parede ventral do abdômen, bem como entre retículo e baço e/ou diafragma. A esplenite traumática foi confirmada no exame post-mortem e as lesões observadas estão relacionadas com o direcionamento do CEM. Portanto, é possível concluir que os achados laboratoriais são condizentes com a severidade da enfermidade e que a ultrassonografia, aliada aos exames clínico e laboratorial, constitui um importante método de diagnóstico. 